\title{
Literatúra omylu: O interdiskurzívnej analýze negatívneho a liminálneho poznania (s príkladmi z fikcie Teda Chianga)
}

\section{PETER GETLÍK}

DOI: https://doi.org/10.31577/WLS.2021.13.4.6

Diskurzívny charakter literatúry sa v súčasnosti konkretizuje výrazne nad rámec všeobecných indícií Michela Foucaulta $(2006,33)$ najmä s využitím metód systémovo-teoretického uvažovania o literatúre, no posun od tvorby k udalosti, od jednoty $\mathrm{k}$ serialite, od originality $\mathrm{k}$ regularite a od významu k možnosti ostáva dominantnou charakteristikou pomerne širokého spektra metodologicky odlišných prístupov sústredených pod zastrešujúci pojem diskurzívnej analýzy.* Zo štyroch princípov sa v našom príspevku v najvýraznejšom napätí prejaví dynamika medzi originalitou a regularitou, kedže charakter umeleckej transformácie a komunikácie negatívneho a hraničného poznania, ktorý si kladieme za ciel' mapovat primárne s dôrazom na vymedzenie zodpovedajúceho teoreticko-metodologického inštrumentária, sa $\mathrm{v}$ závere pokúsime ozrejmit aj na reprezentatívnych literárnych výpovediach amerického spisovatela čínskeho pôvodu Teda Chianga (1967).

V zbierkach poviedok špekulatívnej fikcie Príbehy vášho života (2017; Story of Your Life, 1998) a Výdych (2020; Exhalation, 2008) si budeme všímat' komunikáciu poznania v niekol'kých systémových intersekciách, kedže z hladiska analýzy diskurzu je Chiang sociálnym aktérom, ktorého si Reiner Keller modelovo predstavuje ako „stojaceho v prestrelke viacerých a heterogénnych, možno dokonca kontradikčných diskurzov" (2011, 54; pokial nie je uvedené inak, prel. P. G.). Predstavíme spôsob, akým Chiang pri kreovaní fikčných svetov invenčne recykluje vyvrátené vedecké poznatky, a vd’aka integrujúcej oblasti výskumu kontrafaktuálov, ktoré do žiaducich súvislostí s prezentovanou metodologickou líniou kolektívne spracovali Dorothee Birke, Michael Butter a Tilmann Köppe (2011), objasníme, prečo sa daný postup prejavuje lokálnou originálnostou, ale zároveň systémovou univerzálnostou v žánrovom aj epistemickom kontexte.

\section{INTERDISKURZ A TEÓRIA KONCEPTUÁLNEJ INTEGRÁCIE}

Kedže intersubjektívna sedimentácia ako spoločné poznanie získava v perspektíve sociálneho konštruktivizmu Petra L. Bergera a Thomasa Luckmanna ([1966] 1991, 85) sociálny charakter až objektivizáciou v znakovom systéme, otázku vzájomnej komunikácie diferencovaného poznania prostredníctvom literatúry možno

* Príspevok je výstupom grantového projektu APVV-19-0244 „Metodologické postupy v literárnovednom výskume s presahom do mediálneho prostredia“. 
sústredit do problému integrácie znakových systémov. Zjednotenie diskurzov alebo disparátnych systémov v umení je podla Niklasa Luhmanna $(2000,48)$ nevyhnutne aj synchronizáciou, čím sa zároveň obmedzuje ich sloboda v čase. Kedže rozšírenie lokálne nahromadených poznatkov závisí v konkrétnom čase od ich vzájomnej kompatibility, diskrepancie medzi diskurzmi možno v literatúre využit pri prepájaní vyvrátených, ale niekedy laicky rozšírených poznatkov, ktoré si vzájomne poskytujú literárne plauzibilné podložie. Zlučovanie už vyvrátených poznatkov v interdiskurzívnych súvislostiach sa potom môže zdat problematické z pohladu samostatných systémov, v ktorých dominuje úsilie šírit aktuálne poznanie.

Zdanlivá nekompatibilita medzi uvažovaním o potenciálnych epistemických funkciách literatúry a konštruovaním poznania $\mathrm{v}$ iných sociálnych systémoch ako ich cez operatívnu uzavretost' a autopoietický charakter definuje Luhmann $(2000,2)$ - sa sústreduje v dvoch zásadných ohniskách. Prvý bazálny problém súvisí s kódovaním pravdivý/nepravdivý (63), ktoré sa neraz stáva irelevantné v holistickom pohlade na literatúru. Druhá výzva, ktorú Luhmann naznačuje v aspekte domnelej neužitočnosti umeleckých foriem (126) a paradoxnej pravdepodobnosti výskytu nepravdepodobného literárneho produktu (214), vyplýva z literárneho odklonu od normalizovaného ideálu absolútnosti (potreba hromadit poznanie ad infinitum) $\mathrm{k}$ ideálu relatívnosti (redukovanie množstva informácií v prospech estetickej funkcie).

K pochopeniu procesu komunikácie poznania v literatúre chceme dospiet analýzou interdiskurzívnej povahy literatúry vo vzţahu k špeciálnym diskurzom (najmä vedeckým), pričom rámcovo nadväzujeme na terminologický aparát výskumného programu SKAD (Sociology of knowledge approach to discourse), ako ho zhŕňa Reiner Keller (2013, 72 - 74), a spolu s ním zdôrazňujeme nevyhnutnost' hermeneuticko-interpretatívnych postupov $\mathrm{v}$ transparentných podmienkach $(69-70)$. Pohybujeme sa teda vo vyznačených metodologických vektoroch konštruktivizmu, ale s dôrazom na jeho kognitívnu vetvu, ktorú pri analýze interdiskurzu signalizuje aj Jürgen Link pojmom kolektívnej symboliky $(2013,13)$, čím udržiava prienik s dominantnou kognitívnovednou teóriou konceptuálnej metafory Georga Lakoffa a Marka Johnsona ([1980] 2003). Jürgen Link sa pojmom kolektívnej symboliky pokúša vyhnút terminologickým sporom pri pomenovaní rôznych typov obraznosti, čo (obzvlášt v súvislosti s metonymiou) nie je triviálne úsilie, no v našom výskume výraznejšie metodologické obmedzenie predstavuje skôr unilaterálnost̉ konceptuálnej metafory, pri ktorej sa vzorce prenášajú z jednej zdrojovej do jednej cielovej domény (Lakoff - Johnson 2003, 53).

Pre skúmanie vzájomných vztahov vedecky pravdepodobných aj nepravdepodobných premís pri vzniku komplexných fikčných svetov bez toho, aby sme niektorej zložke a priori priradili primárnu pozíciu v obrazotvornom procese, má zmysel aplikovat teóriu konceptuálnej integrácie Gillesa Fauconniera a Marka Turnera (2002). Popri jej výraznej kompatibilite s teóriou konceptuálnej metafory, ktorá je stále užitočným metodologickým nástrojom, pripúšta teória konceptuálnej integrácie (45) rovnocenné postavenie medzi aspoň dvoma vstupmi (input space), ktoré sú cez všeobecné prieniky (generic space) premietané do jedného koherentného výstupu 
(blended space). Uvedený metodologický nástroj je preto $\mathrm{v}$ analýze interdiskurzu simultánne aplikovatelný vo viacerých úrovniach komplexnosti. Dalšou výhodou teórie konceptuálnej integrácie je, ako uvádza Jana Kuzmíková $(2014,18)$, dôraz tohto prístupu na emergentný charakter novovzniknutých konceptov.

\section{NEGATÍVNE A HRANIČNÉ POZNANIE V (NE)MOŽNÝCH SVETOCH}

Prostredníctvom koncentrácie na vyvrátené poznatky špeciálnych diskurzov sa teoreticky posúvame $\mathrm{k}$ negatívnym a liminálnym formám poznania, ktoré Karin Knorr Cetina $(1999,64)$ asociuje s delimitujúcou funkciou konštruovania poznania. Vyvráteniu vedeckých poznatkov predchádzajú omyly a v ich korekciách a korekciách korekcií (67) spočíva autoreferenčnost' systému vedy, preto aj v zmysle Foucaultových $(2006,21)$ tvrdení o tom, že súčastou medicíny či botaniky sú tak pravdy, ako omyly, môžeme hovorit’ o aktuálnosti a neaktuálnosti jednotlivých vedeckých výpovedí bez nivelizácie ich pevnej pozície v sociálnych systémoch. Kontinuitu faktov a omylov namiesto radikálnej opozície podrobne popisuje na začiatku minulého storočia už Ernst Mach, podla ktorého „chyba nastáva, iba ak vnímame pokračovanie faktu $\mathrm{v}$ existencii za iných okolností a ignorujeme zmenu okolností, fyzických, mentálnych či oboch“ ([1905] 1976, 84). V rámci samostatných špeciálnych diskurzov je síce stále rozhodujúci rozdiel medzi charakterom pozitívneho a negatívneho poznania, ktorý sa prejavuje s časovým odstupom, no z hladiska kognitívnych procesov je uvedený posun v konkrétnej iterácii konštrukcie poznania metodologicky irelevantný, kedže „poznanie aj omyl pramenia z rovnakých mentálnych zdrojov" (Swirski 2007, 120).

S prihliadnutím na proces konceptuálnej integrácie pozitívneho a negatívneho poznania v literatúre, pri ktorom emergentne vznikajú koncepty s novými kvalitami, možno čiastočne zohladnit aj naratologický problém vztahu možných a nemožných svetov, ktorý do literárnovedného povedomia výraznejšie uvádza Lubomír Doležel (1998). Thomas G. Pavel $(1986,44)$ ešte nemožné a možné svety chápe ako vzájomne sa vylučujúce a ontologicky izolované reality, no ich vzt̉ah sa v súčasnosti (najmä v kognitívnej línii naratológie) opisuje skôr gradientom (Ryan 1991, 32). Vlastnosti (ne)možných svetov, ktoré radikálnym spôsobom kombinujú nomologicky nemožné (Klauk 2011,38) a zároveň naratívne štandardné premisy do súdržnej naratívnej simulácie, sa teda nesnažíme diskrétne zjednodušovat', naopak, osciláciu medzi možnostou a nemožnostou rešpektujeme. Rozdiel medzi možnostou a nemožnostou sveta nemusí byt' evidentný v schopnosti predstavit si odlišnosti vyplývajúce z logicky neprijatelných premís. Klauk (37) pripomína Descartov mnohouholník s tisíckou uhlov a mnohouholník s tisícjeden uhlami - v mentálnom obraze vyzerajú rovnako, lísia sa v našom chápaní. Špekulatívna fikcia je schopná simulovat nelogický fikčný svet, $\mathrm{v}$ ktorom 1 = 2 bez toho, aby sa náš mentálny obraz fikčného sveta líšil od obrazu reálneho sveta - identickú matematickú premisu predstavuje Ted Chiang v analyzovanej poviedke Delenie nulou (2017, 71 - 87).

Vývoju v naratológii zodpovedá aj paralelné terminologické rozvíjanie pojmu kontrafaktuál vo fikčnom svete do podoby kontrafikcionálov (Dohrn 2011, 45). Napriek istým odlišnostiam v kognitívnej lingvistike a analytickej filozofii (Birke - 
Butter - Köppe 2011,4) možno zhrnút prieniky oboch pohladov na kontrafaktuály do schopnosti mentálne konštruovat alternatívne reality (1). V prípade kontrafikcionálov sa konkretizujú tieto procesy v rámci fikčných svetov (Dohrn 2011, 45). Aplikovanie teórie kontrafaktuálov na fikčné svety konštruované kombináciou aktuálnych a neaktuálnych vedeckých poznatkov nie je obmedzené ani latentnostou už odmietnutých vedeckých perspektív, ktoré sa podla Luhmanna $(2000,140)$ ukladajú $\mathrm{v}$ rezervoároch $\mathrm{v}$ prípade, že by sa neskôr pod vplyvom nových dôkazov ukázala ich opodstatnenost'. Ak sa $\mathrm{v}$ autokorekčnom mechanizme špeciálnych diskurzov (nateraz) ukáže, že pôvodný omyl je predsa adekvátnou definíciou reality v zmysle vyššie popísanej kontinuity pravdy a omylu u Ernsta Macha, možno prehodnotit kontrafaktuálnost' samostatných výrokov, ale nie kognitívny proces kontrafaktuálneho podmieňovania (Klauk 2011, 31).

Kontrafaktuálne podmieňovanie simuluje alternatívu $\mathrm{k}$ tomu, čo sa rozpoznáva ako faktuálnost’ a čo je v literárnej výpovedi z hladiska kognitívnej lingvistiky jazykovo identifikovatelné (Hilpert 2011) napríklad v negáciách, modalite (mohlo by), príčinnosti (vedie $k$ ), podmienkach (pretože), atributívnych konštrukciách (pravdepodobný kandidát) či v skladaní slov (hrochopes). Metodologicky relevantné je konanie sociálneho aktéra (tvorcu literárneho diela) a jemu dostupný stav poznania pri formulovaní literárnych (jazykových) výpovedí - v opačnom prípade by sa metadiskurzivita interdiskurzívnej analýzy rozptýlila $\mathrm{v}$ jednotlivých špeciálnych diskurzoch a ten, koho Luhmann opisuje $(2000,138)$ ako pozorovatela druhého rádu, by sa stal pozorovatelom prvorádovým $\mathrm{v}$ nekonečnej snahe overovat stav faktuálnosti literárnych výpovedí.

V konceptuálnej integrácii špekulatívnej fikcie sa môže kontrastným efektom (Roese - Morrison 2009, 19) zdôrazňovat v juxtapozícii aktuálna realita a zároveň znejasňovat pozícia pozitívneho a negatívneho poznania. Logické zákony neprotirečenia (Ryan 1991, 32) a vylúčenia tretieho (Ronen 1994, 54) sú štandardne klúčové pre definovanie nemožných svetov, kedže konceptuálne reprezentujú nemožnost paralelnej pravdivosti rozporuplných výrokov, akým je tiež spomínaná rovnica $1=2$. V literatúre (oproti filozofii) tieto zákony podla Doležela $(1998,68)$ nemôžu mat dominantnú pozíciu pre ich problematickú aplikáciu na emočný život, v ktorom sa literárna komunikácia centralizuje. Kedže v literárnych výpovediach špekulatívnej fikcie sa však logické zákony a ich porušovanie nezriedka explicitne tematizujú, je nevyhnutné, aby sme s týmito termínmi dalej operovali rovnako ako s pomenovaním možných a nemožných svetov, aj ked’ im v analýze interdiskurzu nemôžeme priradit metodologicky limitujúcu funkciu.

\section{MYŠLIENKOVÝ EXPERIMENT}

$S$ podobným dôrazom na spájanie rôznych funkcií literárneho interdiskurzu, ktoré sa prejavujú v kognitívnej naratológii, je potrebné pristúpit aj ku genologickým aspektom problému, a hoci vítame isté pragmatické dôsledky tejto perspektívy, náš zámer nevyplýva primárne zo snahy vyhnút sa „zdíhavej meditácii nad definíciou science fiction, často v snahe odlišit ju od iných foriem špekulatívnej fikcie, ako fantasy a horor" (Booker - Thomas 2009 [Thomas 2013, 15]). Napriek nášmu zvýšené- 
mu záujmu o prvky vedeckej fantastiky, ktoré odhalujú vztahy špeciálnych diskurzov v literárnej komunikácii, nie je nevyhnutné sústredit’ sa na taxonomické tažkosti pri spojených žánroch, ale skôr akceptovat ich funkčné zlúčenie. Peter Nicholls (Clute - Nicholls 1993, 1144 - 1145) si v historických súvislostiach všíma, ako sa pojem špekulatívnej fikcie, ktorý bol pôvodne podmnožinou a neskôr synonymom pre pomenovanie vedeckej fantastiky, stáva prienikovým až inkluzívnym termínom pre rôzne žánre - obzvlášt sci-fi a fantasy. Nicholls (1145) čiastočne preberá argumentáciu kritiky namierenej na nepresnost jeho definície, ale už ako obhajobu nového pojmu, kedže sa termín špekulatívna fikcia uplatnil práve preto, aby pôvodné žánrové hranice zjemnil, a odrážal tak skutočný stav súčasnej tvorivej činnosti. S rovnakým zámerom hovoríme o špekulatívnej fikcii aj pri autoroch ako Ted Chiang a i., ktorých tvorba je charakterizovatelná skôr perifériou a prienikom než žánrovým centrom sci-fi, fantasy alebo alternatívnej histórie. Pre náš výklad je rozhodujúci práve špekulatívny aspekt jeho literárnych výpovedí, $\mathrm{v}$ ktorých rozvíja kontrafaktuály z negatívneho a hraničného poznania špeciálnych diskurzov.

$\mathrm{V}$ interdiskurzívnej analýze smerujúcej $\mathrm{k}$ regularite si treba pri konštruovaní poznania obzvlášt pozorne všímat všeobecné postupy myšlienkového experimentu, ktorému Peter Swirski právom prisudzuje titul „kognitívneho švajčiarskeho nožíka“ $(2007,10)$. Swirski zároveň pripomenutím historických románov zdôrazňuje, že v literatúre „nie všetko poznanie možno vystopovat $\mathrm{k}$ myšlienkovým experimentom“ (4). Rozlišovaciu matricu literárneho poznania a myšlienkového experimentu doplňa Tobias Klauk $(2011,32)$ rozčlenením myšlienkového experimentu do troch krokov, pričom dokazuje, že literatúra tento experiment nevyužíva $v$ plnej miere. Z predstavenia si scenára, posudzovania scenára a finálneho úsudku sa literatúra - na rozdiel od využitia myšlienkového experimentu vo filozofii - často zastaví pri prvom či druhom kroku.

Formálne prekrytie myšlienkového experimentu a poznávania v literatúre v žánroch špekulatívnej fikcie korešponduje s ideovými prienikmi literárneho a vedného diskurzu a ich synchronizačnými procesmi. $V$ uvedenom zmysle sa podla Matthewa J. Wolf-Meyera $(2019,5)$ od 19. storočia otázky antropológie, sociológie a psychológie prelínajú s motiváciami spisovatelov špekulatívnej fikcie, vdaka čomu sú „sociálna teória a špekulatívna fikcia dvoma stranami tej istej mince“ (5). Vzhladom na účast' myšlienkových experimentov, ale aj menej komplexného kontrafaktuálneho podmieňovania pri formovaní poznania príbuzného sociálnej teórii, možno najvýraznejšie žánrové paralely k sci-fi pozorovat v literárnych utópiách. Ako si Juraj Malíček $(2018,110)$ všíma v dielach Ayn Rand, významným prienikom sci-fi a utópie je pocit úžasu (sense of wonder), vd’aka ktorému začíname o týchto žánroch uvažovat v kontexte špekulatívnej fikcie. Schopnost̉ špekulatívnej fikcie vyvolat pocit úžasu cez kontrastný efekt sa podobá na koncepčne radikálne myšlienkové experimenty, $\mathrm{v}$ ktorých sa nezriedka realizuje postup reductio ad absurdum, teda nasledovanie propozícií do extrémnych záverov v snahe poukázat na ich neudržatel'nost' (Green 2010, 359). K takémuto odhaleniu dochádza najmä prostredníctvom efektu kauzálnej inferencie (Roese - Morrison 2009, 19), pri ktorej možno vyvodit závery vo vztahu k aktuálnemu svetu. 


\section{LITERÁRNY SYSTÉM V KOGNITÍVNEJ PERSPEKTÍVE KONTRAFAKTUÁLNYCH FUNKCIÍ}

Spôsob formovania literatúry pod vplyvom konštruovania poznania možno zretel'ne sledovat' pomocou dvoch funkcií kontrafaktuálov (afektívnej a prípravnej). Vdaka afektívnej funkcii kontrafaktuálov (19) sa cítime lepšie (alebo horšie) pri porovnaní zažitých faktuálov a simulovaných kontrafaktuálov, čo sa aktívne využíva v literárnych textoch, ktoré menia perspektívu čitatela na vlastný život. Zmeny v simulácii kontrafaktuálov môžu zasiahnut aj do zásadnejších kognitívnych vzorcov, a ovplyvnit tak dlhodobé správanie čitatel'skej verejnosti, pričom tento predpoklad je v literárnej vede dávno axiomatický, no potvrdzuje sa už aj v metodologicky exaktnejšom prostredí psychológie, $\mathrm{v}$ ktorej „[n]iekolko stoviek štúdií demonštrovalo vplyv kontrafaktuálneho premýšlania na široké spektrum úsudkov, rozhodnutí, emócií a správania“ (18).

Literatúra tak môže komunikovat aj poznanie, pre ktoré je kódovanie pravda/ nepravda úplne irelevantné. Okrem klasického propozičného poznania rozlišuje Mitchell Green $(2010,352)$ aj fenomenálne poznanie (aké je to niečo zažit, cítit') a poznanie ako niečo robit. U Erkkiho Sevänena (2018, 63 - 64) poslednú kategóriu nachádzame pod pojmom procedurálne poznanie a možno ho približit cez techniku, metódu alebo schopnost vykonávat konkrétnu činnost'. Literatúra (a programovo žáner sci-fi) môže komunikovat špecializované poznanie vo forme metód vedeckého uvažovania, ako je napríklad práve myšlienkový experiment, alebo prostredníctvom obrazne začleneného terminologického aparátu „generovat rámcové kontexty na ulahčenie porozumenia všeobecných teórií vyvinutých inde“ (Swirski 2007, 35).

Pomocou prípravnej funkcie kontrafaktuálov (Roese - Morrison 2009, 20), ktorá je výrazná aj v žánrovom podloží vedeckej fantastiky v podobe varovaní, sa pokúšame simulovat prípadné budúce nebezpečenstvá a vyhnút sa im. Rovnako je možné naznačit aj funkčnú príbuznost' hororu a sci-fi. Wolf-Meyer $(2019,3)$ uvažuje o paralelách sociálnej teórie a špekulatívnej fikcie práve na základe ich schopnosti predpokladat nečakané nebezpečenstvá. Rovnaké indície o jednej z mnohých funkcií literárneho systému sú viditel’né aj v experimentálnych kognitívnych výskumoch, vdaka ktorým je evidentné, že „pacienti s poruchami prefrontálnej mozgovej kôry trpia neschopnostou formovat koherentné reprezentácie alternatívnych alebo kontrafaktuálnych realít" (Holland 2007, 69). Takíto pacienti s dysnaratíviou (69-70) konajú v neprimeranej (okamžitej) spätnej väzbe vzhladom na vonkajšie prostredie - ak je pred nich položený hrebeň, začnú sa česat. $V$ opozícii $k$ absolútnej kontrole vonkajšieho prostredia nad správaním človeka sa nachádzajú hravé, nepravdepodobné či nepredvídatelné formy správania, s čím je konzistentný aj fakt, že v porovnaní s dysnaratíviou má v zdravom mozgu rovnaká oblast' „podstatnú úlohu v spontánnom generovaní pohybu" (Passingham 1993 [Holland 2007, 69]).

Po naznačených kognitívnych paralelách k vlastnostiam literárneho systému je vhodné sa vrátit k Luhmannovým vyjadreniam o umeleckej „paradoxnej pravdepodobnosti nepravdepodobného" $(2000,214)$. Čo sa v niektorých sociálnych systémoch môže javit ako redundantné, teda hravost', spontánnost’ a zdanlivá neužitočnost' umenia, zdá sa, koreluje s rozvinutím (nielen tohto) evolučne selektovaného 
a funkčného princípu, ktorý sa prejavuje aj v literárnom systéme, čím sa nepravdepodobné výpovede dostávajú z periférie do centra pozornosti tohto systému. Špekulatívna fikcia kombinujúca faktuály a kontrafaktuály v procese konceptuálnej integrácie do nepravdepodobných fikčných svetov nie je anomáliou, ale systémovým extrapolovaním daného princípu. Zdanlivé obavy z nekompatibility medzi poznávacou funkciou interdiskurzu literatúry a špeciálnych diskurzov vedeckých disciplín sú tak z pohladu pravdivosti i užitočnosti literárnych výpovedí neopodstatnené. Využitelnost prezentovaných teoreticko-metodologických nástrojov preto môžeme overit ich aplikáciou v analýze, pri ktorej sa zhrnuté princípy odkryjú v literárnej výpovedi Teda Chianga.

\section{TED CHIANG - OD ORIGINALITY K REGULARITE}

Teda Chianga aj napriek skromnosti jeho diela, ktoré v súčasnosti predstavujú spomenuté zbierky Príbehy vášho života a Výdych, možno považovat za jedného z najoceňovanejších (Booker 2015, 61 - 62) autorov špekulatívnej fikcie. Jeho literárne výpovede sa najčastejšie spájajú s metadiskurzívnym štýlom (Sevänen 2018, 80) Jorgeho Luisa Borgesa, ktorým Chiang tematizuje interdiskurzívnu funkciu umenia pri konštruovaní poznania. V poviedke „Pochop“ (2017, 32 - 70) proti sebe stavia v ideologickom i doslovnom smrtelnom zápase altruistickú a estetickú motiváciu poznávania. V krátkom beletristickom príspevku „Vývoj ludskej vedy“ (2017, 187 189), pôvodne spracovanom do rubriky „Futures“ časopisu Nature, sa zamýšla nad hermeneutickou budúcnostou ludskej vedy, ktorej jediný efektívny spôsob poznávania je interpretácia už dávno akumulovaných, ale intelektuálne neprístupných poznatkov nadludí.

Regularitu interdiskurzívnej komunikácie špeciálnych diskurzov v Chiangových literárnych výpovediach možno najefektívnejšie demonštrovat poukázaním na habituálnost' postupov, ktoré identifikujeme v poviedke „Delenie nulou“ (2017, 71 87). Autor si v nej predstavuje svet, v ktorom sa rozpadá konzistentnost matematiky, čo je podla neho „jedna z najhorších možných správ“ (255). Komunikácia špeciálnych diskurzov sa sústreduje vo výrokoch fiktívnych sociálnych aktérov vo vzájomnej väzbe v podobe vedeckého manželského páru - matematičky Renee a biológa Carla. Renee objaví formalizmus, v ktorom je evidentná rovnost' medzi lubovolnými dvoma číslami, vdaka čomu sa u nej narušia kognitívne schémy rozlišujúce rôzne gestalty. Dôkaz, že $1=2$, je geniálna matematička schopná transponovat na dalšie zdanlivo separátne javy a svoj úsudok extrapoluje do záveru, že „život a smrt’ sa rovnajú" (82).

Matematika ako formálny systém, v ktorom sa má manifestovat koherentnost fikčného sveta, už nenapíňa logické zákony neprotirečenia a vylúčenia tretieho, preto nihilistická konštrukcia reality osciluje medzi možnostou a nemožnostou a Renee sa v perspektíve ich vzájomnej zamenitel’nosti pokúša o samovraždu. Komunikácia špeciálnych diskurzov je v poviedke kompozične stratifikovaná do deviatich úrovní, ktoré sú rozčlenené trojicou sekcií označovaných ako $1,1 \mathrm{~A}, 1 \mathrm{~B}$, kde prvá časṫ vždy rozvíja všeobecnú historicko-matematickú paralelu v podobe diskurzívnych fragmentov o potrebe dokázat’ konzistentnost’ aritmetiky. Označenie A potom uvádza 
perspektívu Renee a označenie B pohlad jej manžela. Posledná, už dvojčlenná deviata iterácia $(9,9 \mathrm{~A}=9 \mathrm{~B})$ vrcholí demonštratívnou juxtapozíciou manželov a ich svetonázorov vdaka Carlovej záverečnej empatii k samovražedným sklonom manželky, „ktorá ich nespájala, ale rozdelovala“ (87).

Poviedka „Delenie nulou“ rozvíja hraničné poznanie o konzistentnosti aritmetiky a, $v$ súlade $s$ Hilbertovým programom, aj komplexnejšej matematiky (Raattkainen 2005, 514). Kurt Gödel „zasadil smrtelnú ranu Hilbertovmu programu“ (513), ked” v dvoch známych teorémach dokázal, že každý konzistentný formálny systém obsahuje výroky, ktoré sú pravdivé, ale nedokázatel’né v rámci daného systému, a že žiaden konzistentný formálny systém nemôže dokázat vlastnú konzistenciu (513). Tieto závery mohol vyvodit vdaka zavedeniu (v matematike dovtedy nepoznanej) metadiskurzívnosti (Gödel 1992), pomocou ktorej sa systém matematiky vie prvý raz autoreferenčne komplexne charakterizovat výhradne pomocou matematického jazyka, podobne ako to robí metadiskurzívna literatúra.

Gödel liminálnym poznaním ohraničil poznávaciu schopnost̉ matematiky, čím dekonštruuje ideál absolútneho poznania, ked’ potvrdí, že „pravda nie je zamenitelná s dokázatel'nostou v žiadnej efektívne axiomatizovatel'nej teórii“ (Raattkainen 2005, 516). Evidentná príbuznost podobných záverov a metadiskurzívnosti jazykových paradoxov nie je náhodná a sám Gödel $(1992,40)$ pri vysvetlovaní svojich matematických ideí využíva paralelu k Richardovej antinómii či známemu paradoxu klamára, ktorý vytvára nekonečný rekurzívny rozpor vo výroku luhára: „Klamem.“

$\mathrm{Na}$ Gödelove teorémy sa zvykne odkazovat' v kontexte mysticizmu ako na dôkaz nadprirodzeného na pozadí „kozmickej signifikantnosti matematiky“ (Stableford 2006, 288), ktorá sa výrazne popularizuje aj v žánri sci-fi, no napriek pridaným metafyzickým implikáciám výrokov o nedokázatel’nosti velkých právd „samy osebe tieto výsledky nemajú žiadne také implikácie“" (Raattkainen 2005, 529). Nie je preto vhodné automaticky priradit možným metafyzickým interpretačným líniám interpretačný prím, pretože, ako sa ukazuje aj v aplikácii kognitívnovedného prístupu k tvorbe Teda Chianga, pre ich diverznú funkciu nemožno „na základe umeleckého využitia metafyzických variácií metafor jednoznačne vyvodzovat teleologické interpretácie [Chiangových] diel“ (Getlík 2020, 72).

Chiang teda nie metafyzikou, ale jej dekonštrukciou v postupe reductio ad absurdum aj v poviedke „Delenie nulou“ prináša možnost' v kontrastnom efekte vyvodit záver o zmysluplnosti života, čo naznačuje tiež interpretačným klúčom v názve poviedky, ktorý odkazuje na formálnu chybu schovanú v literárnom kontrafaktuálnom podmieňovaní. Po aplikácii neplatného kroku (delenia nulou) sa dajú matematicky vyvodit nekonzistentnosti typu $1=2$. Integrácia pravdepodobných a nepravdepodobných premís je literárne ukrytá v exaktnej a vernej demonštrácii matematického kontextu a odhalí sa až v deviatej uvádzacej sekcii, ktorá príznakovo obsahuje iba citát Alberta Einsteina odrážajúci skutočný charakter Gödelových záverov: „Pokým matematické tvrdenia zobrazujú realitu, nie sú isté. A pokým sú isté, nevyjadrujú realitu“" (Chiang 2017, 87). Prevzatý výrok je teda parciálnym interpretačným klúčom $\mathrm{k}$ identifikácii aktuálnych poznatkov špeciálneho diskurzu na pozadí pochopenia neaktuálneho poznatku v naratívnej rovine príbehu. Druhou častou, ktorú reprezentuje 
Carl, je chápanie aktuálnych biologických poznatkov, ktoré v súčasnosti vyvracajú esencializmus života poukázaním na fakt, že živé je komplexom neživého a niekedy neživé simplicitnou podobou života (napr. aminokyseliny).

Renee si je taká istá svojou pravdou, až stratí zmysel života, no práve istota, ktorú nadobudla, by bola v rekurzívnej negácii signálom, že jej tvrdenia nevyjadrujú realitu a znova k prvému kroku ad infinitum. Omyl, ktorého sa Renee vo svojej literárne predstavenej logike mohla dopustit, je prerušenie rekurzívneho cyklu v konkrétnej iterácii, čo je v rozpore s tým, že podstata poznania Gödelovej vety je v poukázaní na možnosti neobmedzeného expandovania jazyka a matematiky (Raattkainen 2005, 528). Práve samovraždou by mohla overit', že život a smrt’ nie sú zamenitelné, ale obmedzila by svoju schopnost' komunikovat toto poznanie v sociálnom systéme. Nezamenitelnost svetov života a smrti je tu gödelovsky evidentne pravdivá, no nedokázatelná axióma. Konzistentne s tvrdením Petra L. Bergera a Thomasa Luckmanna sa takto v Chiangovej literárnej výpovedi zdôrazňuje, že „[s]trategická legitimizačná funkcia symbolického univerza pre individuálnu biografiu je ,lokácia smrti“ ([1966] 1991, 118). Schopnost’ integrácie a legitimizácie smrti je zásadné kritérium, na základe ktorého sa poznanie špeciálnych diskurzov v skúmaných literárnych výpovediach selektuje a prispôsobuje, pretože aj pri rozpade pôvodných hodnôt (najčastejšie v súvislosti s úmrtím blízkeho) musíme „umožnit jedincovi pokračovat v živote v spoločnosti“ (119).

Metaforika, ktorou Chiang integruje špeciálne diskurzy, sa vyznačuje regularitou v zlučovaní analytických a holistických perspektív, čo možno parciálne vysvetlit aj jazykovo-kultúrnou pozíciou autora Američana čínskeho pôvodu. Tendencie k analytickejšiemu premýšlaniu Američanov a Američaniek a holistickejšej perspektíve obyvatelov Východnej Ázie dokazuje už rozsiahle spektrum empirických štúdií zhrnutých Richardom E. Nisbettom (2003). Najčastejšie tieto štúdie odpovedajú na otázky pozornosti a percepcie, vnímania kauzality, organizácie poznatkov a uvažovania. Reprezentatívnym príkladom zamerania týchto výskumov a ich záverov môže byt experiment s kategorizáciou pojmov. Pri jej skúmaní sa ukazuje (140), že geografický pôvod je štatisticky relevantný pri združovaní slov z trojice krava, tráva, sliepka. Obyvatelia Východnej Ázie majú meratelnú tendenciu združovat' kravu a trávu ako cyklický vztah (holistické združenie pojmov) a probandi z Ameriky skôr sliepku a kravu ako súčasti kategórie zvieratá (analytické združenie). Uvedené rozdiely v jazyku a premýšlaní sú najbadatelnejšie v konceptuálnom vnímaní času. Oproti angličtine, v ktorej absolútne dominuje horizontálna konceptuálna metafora času, má mandarínčina aj výrazne silnú vertikálnu konceptuálnu metaforu, v ktorej čas padá (Boroditksy 2001, 5), čo pravdepodobne súvisí aj so smerom čítania čínskeho písma zhora nadol. Prieniky konceptov horizontálneho a vertikálneho času v tvorbe Teda Chianga podrobnejšie dokazujeme inde (Getlík 2020), no naznačená téma sa časovým rozmerom nevyčerpáva.

$\mathrm{Na}$ integráciu rozdielnych diskurzov Chiang použiva koncepty ekvivalencie, ako sú obrazotvorné možnosti rovníc, palindromických štruktúr a symetrickej geometrie. Opozícia analytickej a holistickej perspektívy je čiastočne v súlade $s$ členením prírodných (s výnimkou biológie) a humanitných vied, no obrazne možno hovorit skôr o kontraste "neživých“ a „živých“ špeciálnych diskurzov. Motivácia na ich spojenie sa pravidelne udržiava v sociálnom prijatí smrti a zachovaní (sociálneho) života. V po- 
viedke „Omfalos“ (2020, 205 - 232) sa pri vzniku kreacionistického fikčného sveta postupom reductio ad absurdum navzájom podporujú negatívne poznatky archeológie o objavených protostromoch (bez starších letokruhov), protoulitách (bez centra špirály) a protoludoch (bez pupočnej diery) a vyvrátené poznatky astronómie a fyziky o geocentrizme a relatívnej rýchlosti svetla vo vákuu - všetko s cielom ilustrovat pokračovanie zmysluplného života vo fikčnom svete, ktorý je nad všetku pochybnost’ Bohom stvorený, no ignorovaný. V „Príbehu tvojho života“ (2017, 88 - 137) sa pre zachovanie zmyslu existencie matky (jazykovedkyne), ktorá vidí v budúcnosti nezvratnú smrt svojho dietata a na rozdiel od manžela (fyzika) ju prijíma s pokorou, spája fyzikálny palindróm Fermatovho princípu (jeho dobové teleologické interpretácie sú už prekonané kvantovou mechanikou) s radikálnou prezentáciou whorfianizmu, ktorý už je $\mathrm{v}$ súčasnosti prijímaný iba $\mathrm{v}$ umiernených podobách. $\mathrm{V}$ poviedke „Sedemdesiatdva písmen“ $(2017,138$ - 186) sa zabráni vymieraniu ludského rodu vo fikčnom svete, $\mathrm{v}$ ktorom Chiang integruje vyvrátenú biologickú teóriu predtvarovania a poznatky fyziky, ktoré už zavrhujú neaktuálnu predstavu o bezstratovej zamenitelnosti tepelnej a mechanickej energie. Antropocentrický rozlišovací klúč špeciálnych diskurzov na komunikáciu inštitucionálneho poznania pre nevyhnutné akceptovanie smrti uvedenými príkladmi nekončí, no už aj toto zhrnutie nám umožňuje vnímat pravidelnosti v interdiskurzívnych výpovediach, ktoré sa individuálne prejavujú originalitou vdaka rekombinácii širokého spektra fragmentov špeciálnych diskurzov.

\section{ZÁVER}

Hlavným cielom tejto štúdie bolo podrobne definovat základný teoreticko-metodologický aparát pre interdiskurzívnu analýzu využitia negatívneho a liminálneho poznania v literatúre, k čomu nám pomohli žánrové aspekty špekulatívnej fikcie, konkrétne identifikovatel'né v literárnych výpovediach Teda Chianga. Jeho rozpoznatel'ná literárna stratégia má jasné kognitívne základy v kontrafaktuálnom podmieňovaní a následnom konceptuálnom integrovaní faktuálov a kontrafaktuálov. V analyzovaných literárnych výpovediach sa intertextuálne a tematicky komunikovalo propozičné poznanie špeciálnych diskurzov. Kompozične sa vytváral priestor pre abstrahovanie procedurálneho poznania prostredníctvom metód vedeckého uvažovania (myšlienkový experiment). Fenomenálne poznanie o ochote žit v nečakane rozpadnutom svete sa tlmočilo naratívnou simuláciou. Overili sme funkčnost' predstaveného teoreticko-metodologického rámca, ktorý možno aplikovat na literárne výpovede, kde sa poznanie nekomunikuje konzistentnostou právd, ale nesúrodostou neprávd.

\section{LITERATÚRA}

Berger, Peter L. - Thomas Luckmann. [1966] 1991. The Social Construction of Reality: A Treatise in the Sociology of Knowledge. 6th Edition. Harmondsworth: Penguin Books.

Birke, Dorothee - Michael Butter - Tilmann Köppe, eds. 2011. Counterfactual Thinking - Counterfactual Writing. Berlín - Boston, MA: de Gruyter. DOI: https://doi.org/10.1515/9783110268669.

Booker, Keith M. 2015. Historical Dictionary of Science Fiction in Literature. Lanham, MD - Boulder, CO - New York, NY - Londýn: Rowman \& Littlefield. 
Boroditsky, Lera. 2001. „Does Language Shape Thought?: Mandarin and English Speakers' Conceptions of Time“. Cognitive Psychology 43, 1 - 22. DOI: https://doi.org/10.1006/cogp.2001.0748.

Clute, John - Peter Nicholls, eds. 1993. The Encyclopedia of Science Fiction. New York, NY: St. Martin's Press.

Dohrn, Daniel. 2011. „Counterfactual Explanation in Literature and the Social Sciences.“ In Counterfactual Thinking - Counterfactual Writing, eds. Dorothee Birke - Michael Butter - Tilmann Köppe, 45 - 61. Berlín - Boston, MA: de Gruyter. DOI: https://doi.org/10.1515/9783110268669.45.

Doležel, Lubomír. 1998. Heterocosmica: Fiction and Possible Worlds. Baltimore, MD - Londýn: The Johns Hopkins University Press.

Fauconnier, Gilles - Mark Turner. 2002. The Way We Think: Conceptual Blending and the Mind's Hidden Complexities. New York, NY: Basic Books.

Foucault, Michel. 2006. Rád diskurzu. Prel. Miroslav Marcelli. Bratislava: Agora.

Getlík, Peter. 2020. „Aplikácia metód kognitívneho výskumu na hraniciach literatúry a filmu: Ted Chiang - Príbeh tvojho života a jeho konceptuálne metafory." Slavica litteraria 23, 2: 61 - 73. DOI: https://doi.org/10.5817/SL2020-2-4.

Gödel, Kurt. 1992. On Formally Undecidable Propositions of Principia Mathematica and Related Systems. Prel. Bernard Meltzer. Mineola, NY: Dover Publications.

Green, Mitchell. 2010. „How and What We Can Learn from Fiction. "In A Companion to the Philosophy of Literature, eds. Garry L. Hagberg, - Walter Jost, 350 - 366. Malden, MA - Oxford - Chichester: Wiley-Blackwell.

Hilpert, Martin. 2011. „A Cognitive Linguistic Perspective on Counterfactuality.“ In Counterfactual Thinking - Counterfactual Writing, eds. Dorothee Birke - Michael Butter - Tilmann Köppe, 95 - 111. Berlín - Boston, MA: de Gruyter. DOI: https://doi.org/10.1515/9783110268669.95.

Holland, Norman. N. 2007. „The Neuroscience of Metafilm.“ Projections 1, 1: 59 - 74. DOI: https://doi. org/10.3167/proj.2007.010105.

Chiang, Ted. 2017. Príbehy vášho života. Prel. Lubomíra Kuzmová. Bratislava: Premedia.

Chiang, Ted. 2020. Výdych. Prel. Marína Gálisová. Bratislava: Premedia.

Keller, Reiner. 2011. „The Sociology of Knowledge Approach to Discourse (SKAD).“ Human Studies 34, 1: 43 - 65. DOI: https://doi.org/10.1007/s10746-011-9175-z.

Keller, Reiner. 2013. Doing Discourse Research: An Introduction for Social Scientists. Prel. Bryan Jenner. Los Angeles, CA - Londýn - Naí Dillí - Singapur - Washington DC: Sage Publication. DOI: https:// dx.doi.org/10.4135/9781473957640.

Klauk, Tobias. 2011. „Thought Experiments and Literature.“ In Counterfactual Thinking - Counterfactual Writing, eds. Dorothee Birke - Michael Butter - Tilmann Köppe, 30 - 44. Berlín - Boston, MA: de Gruyter. DOI: https://doi.org/10.1515/9783110268669.30.

Knorr Cetina, Karin. 1999. Epistemic Cultures: How the Sciences Make Knowledge. Cambridge, MA - Londýn: Harvard University Press.

Kuzmíková, Jana. 2014. „Umenie a kognitívne vedy.“ In Literatúra v kognitívnych súvislostiach, ed. Jana Kuzmíková, 10 - 28. Bratislava: Ústav slovenskej literatúry SAV.

Lakoff, George - Mark Johnson. [1980] 2003. Metaphors We Live By. Chicago, IL: The University of Chicago Press.

Link, Jürgen. 2013. „Diskurs, Interdiskurs, Kollektivsymbolik: Am Beispiel der aktuellen Krise der Normalität." Zeitschrift für Diskursforschung 1, 1: 7 - 23. DOI: https://doi.org/10.3262/ ZFD1301007.

Luhmann, Niklas. 2000. Art as a Social System. Prel. Eva M. Knodt. Stanford, CA: Stanford University Press.

Mach, Ernst. [1905] 1976. Knowledge and Error: Sketches on the Psychology of Enquiry. Prel. Thomas J. McCormack - Paul Folkes. Dordrecht - Boston, MA: D. Reidel Publishing Company.

Malíček, Juraj. 2018. „Filozofia (v) príbehu - filozoficko-estetické čítanie diela Ayn Rand v kontextoch populárnej kultúry.“ World Literature Studies 10, 2: 105 - 112.

Nisbett, Richard. E. 2003. The Geography of Thought: How Asians and Westerners Think Differently... and Why. New York, NY - Londýn - Toronto - Sydney - Singapur: Free Press.

Pavel, Thomas G. 1986. Fictional Worlds. Cambridge, MA - Londýn: Harvard University Press. 
Raattkainen, Panu. 2005. „On the Philosophical Relevance of Godel's Incompleteness Theorems.“ Revue internationale de philosophie 59, 4: 513 - 534.

Roese, Neal J. - Mike Morrison. 2009. „The Psychology of Counterfactual Thinking.“ Historical Social Research 34, 2: 16 - 26.

Ronen, Ruth. 1994. Possible worlds in literary theory. Cambridge - New York, NY - Melbourne: Cambridge University Press.

Ryan, Marie-Laure. 1991. Possible Worlds, Artificial lntelligence, and Narrative Theory. Bloomington, IN - Indianapolis, IN: Indiana University Press.

Sevänen, Erkki. 2018. „Modern Literature as a Form of Discourse and Knowledge of Society.“ Sociologias 20, 48: 48 - 85. DOI: https://doi.org/10.1590/15174522-020004803.

Stableford, Brian. 2006. Science Fact and Science Fiction: An Encyclopedia. Londýn - New York, NY: Routledge.

Swirski, Peter. 2007. Of Literature and Knowledge: Explorations in Narrative Thought Experiments, Evolution and Game Theory. Londýn - New York, NY: Routledge.

Thomas, Paul. L. 2013. "A Case for SF and Speculative Fiction: An Introductory Consideration." In Science Fiction and Speculative Fiction: Challenging Genres, ed. Paul L. Thomas, 15 - 34. Rotterdam: Sense Publishers. DOI: https://doi.org/10.1007/978-94-6209-380-5_2.

Wolf-Meyer, Matthew J. 2019. Theory for the World to Come: Speculative Fiction and Apocalyptic Anthropology. Minneapolis, MN - Londýn: University of Minnesota Press.

\title{
Literature of the mistake: On the interdiscursive analysis of negative and liminal knowledge (with examples from Ted Chiang's fiction)
}

Contrafactual. Godel's theorem. Interdiscourse. Speculative fiction. Ted Chiang.

The main goal of the study is to present the basic theoretical and methodological apparatus for the interdiscursive analysis of the use of negative and liminal knowledge in literature with the focus on speculative fiction. For this purpose, we use the original literary statements of the American writer Ted Chiang, in whose work the regularity of metadiscursive thematization of forms of constructing knowledge is manifested. We operate in the marked methodological vectors of constructivism, but with emphasis on its cognitive branch. The conceptual integration theory and research on counterfactual thinking is applied to connections of multiple special discourses in speculative fiction. Three distinct forms of knowledge (propositional, procedural and phenomenal) are covered in this research to understand the unique role of literature as interdiscourse where knowledge can be communicated by what is untrue or unknown in science.

\author{
Mgr. Peter Getlík, PhD. \\ Katedra slovakistiky, slovanských filológií a komunikácie \\ Filozofická fakulta \\ Univerzita Pavla Jozefa Šafárika v Košiciach \\ Moyzesova 9 \\ 04011 Košice \\ Slovenská republika \\ peter.getlik@upjs.sk \\ ORCID: https://orcid.org/0000-0003-3820-620X
}

